\title{
The role of silicon in plant tissue culture
}

\section{lyyakkannu Sivanesan and Se Won Park*}

Department of Molecular Biotechnology, Konkuk University, Seoul, South Korea

\section{Edited by:}

Agnieszka Ludwików, Adam

Mickiewicz University, Poland

\section{Reviewed by:}

Chanyarat Paungfoo-Lonhienne, The

University of Queensland, Australia

Andrzej Miroslaw Pacak, Adam

Mickiewicz University, Poland

Agnieszka Ludwików, Adam

Mickiewicz University, Poland

${ }^{*}$ Correspondence:

Se Won Park, Department of Molecular Biotechnology, Konkuk

University, 1 Hwayang-dong,

Gwangjin-gu, Seoul 143-701,

South Korea

e-mail: sewpark@konkuk.ac.kr

\begin{abstract}
Growth and morphogenesis of in vitro cultures of plant cells, tissues, and organs are greatly influenced by the composition of the culture medium. Mineral nutrients are necessary for the growth and development of plants. Several morpho-physiological disorders such as hooked leaves, hyperhydricity, fasciation, and shoot tip necrosis are often associated with the concentration of inorganic nutrient in the tissue culture medium. Silicon (Si) is the most abundant mineral element in the soil. The application of Si has been demonstrated to be beneficial for growth, development and yield of various plants and to alleviate various stresses including nutrient imbalance. Addition of $\mathrm{Si}$ to the tissue culture medium improves organogenesis, embryogenesis, growth traits, morphological, anatomical, and physiological characteristics of leaves, enhances tolerance to low temperature and salinity, protects cells and against metal toxicity, prevents oxidative phenolic browning and reduces the incidence of hyperhydricity in various plants. Therefore, Si possesses considerable potential for application in a wide range of plant tissue culture studies such as cryopreservation, organogenesis, micropropagation, somatic embryogenesis and secondary metabolites production.
\end{abstract}

Keywords: acclimatization, epicuticular wax deposition, hyperhydricity, organogenesis, silicon, stress tolerance

\section{INTRODUCTION}

Plant tissue culture is a collection of experimental procedures for aseptic culture of isolated plant cells, tissues or organs on nutrient media under controlled environmental conditions. Growth and morphogenesis of in vitro cultures of plant cells, tissues and organs are greatly influenced by the composition of the culture medium. The composition of a culture medium has often been modified to stimulate the growth of particular plant material. In general, plant tissue culture medium composed of inorganic nutrients, organic supplements, carbon source, plant growth regulators and a solidifying agent. Mineral nutrients are necessary for growth and development of plants. The optimization of inorganic nutrients in the culture medium improves growth and morphogenesis of plant cells, tissues and organs in vitro. Several physiological disorders such as hooked leaves, hyperhydricity, fasciation and shoot tip necrosis are often associated with the concentration of inorganic nutrients in the culture medium (Reed et al., 2013).

Silicon ( $\mathrm{Si}$ ) is the most abundant mineral element in the soil (Epstein, 1999). Numerous studies have shown that Si treatment improves the growth and yield of various plants, particularly when they are subjected to both abiotic and biotic stresses (Ma, 2004). Several researchers have reviewed the role Si on plant tolerance to abiotic (Balakhnina and Borkowska, 2013; Zhu and Gong, 2014) and biotic stresses (Van Bockhaven et al., 2013). The availability of $\mathrm{Si}$ in hydroponic and substrate plant production system is restricted. Addition of Si to the nutrient solution or soilless substrate enhanced growth traits, yield and quality of several crops (Voogt and Sonneveld, 2001). The promoting effects of Si on plants might be due to increasing nutrient uptake and photosynthetic activity. Though $\mathrm{Si}$ is a ubiquitous contaminant, the use of silicon-free containers and double distilled water restricts its availability. Furthermore, Si has not been included in any commercial tissue culture media formulation. The inclusion of Si to the culture medium improved the morphogenetic potential of plant cells, tissues and organs. Several studies have shown that the inclusion of Si to the tissue culture medium enhances callus growth, shoot regeneration, and root induction and stimulates somatic embryogenesis, and improve morphological, anatomical and physiological characteristics of plantlets. In addition, Si treatment prolongs the longevity of calli and organs with a potential for plant regeneration. The inclusion of $\mathrm{Si}$ to the tissue culture medium also enhances tolerance to low temperature, metal toxicity and salinity. Si enhancing tolerance of plants to various stresses by altering activity of antioxidant enzymes, cation binding capacity of the cell walls, endogenous plant hormone level, increasing production of chitinase, glucanse, lignin, phenolics, and phytoalexins, nutrient uptake, improving strength of cell and plant, maintaining the structure of stomata, relative water content, and reducing uptake of heavy metals. This review concentrates the potential roles of Si in plant tissue culture.

\section{ROLE OF SI IN PLANT TISSUE CULTURE ORGANOGENESIS AND SOMATIC EMBRYOGENESIS}

Islam etal. (2005) investigated the effect of calcium silicate $\left(\mathrm{CaSiO}_{3}\right)$ on callus induction and plant regeneration from mature seed explants of rice 'Kalizira', 'Lucky', and 'Pajam'. The highest frequency of callus induction is achieved on Murashige and Skoog (MS) medium containing $\mathrm{CaSiO}_{3}$. However, plant or root regeneration potential of rice calli is cultivar depended. Similarly, effects of Si on plant or root development depend on reed (Phragmites australis) genotype used for callus induction (Mathe et al., 2012). Addition of $\mathrm{Si}$ as sodium silicate $\left(\mathrm{Na}_{2} \mathrm{SiO}_{3}\right)$ to the modified MS medium promotes the growth of calli obtained from stem nodal 
and root explants of $P$. australis while its effect on somatic embryogenesis is explants dependent: it stimulates embryogenesis of root calli, but it does not influence this process in stem nodal calli. Soares et al. (2011) evaluated the effect of Si source [potassium silicate $\left(\mathrm{K}_{2} \mathrm{SiO}_{3}\right)$ and $\left.\mathrm{Na}_{2} \mathrm{SiO}_{3}\right]$ on shoot multiplication of Cattleya loddigesii. The highest number of shoots is observed on the modified Knudson $\mathrm{C}$ medium containing $5.0 \mathrm{mg} \mathrm{L}^{-1} \mathrm{~K}_{2} \mathrm{SiO}_{3}$. In Ajuga multiflora, addition of Si to MS medium containing 2iP and IAA, enhanced adventitious shoot regeneration (about threefold) by increasing the activity of antioxidant enzymes such as SOD, POD, APX, and CAT (Sivanesan and Jeong, 2014). In addition, the authors observed the Si accumulation in leaves of plants developed in the culture medium with Si, but not in plants developed in the medium without $\mathrm{Si}$ by wavelength dispersive $X$-ray analysis. These studies indicate that the effect of Si on morphogenetic potential of in vitro plant cultures depends on plant species, genotype and concentration of $\mathrm{Si}$ in the culture medium. Still further studies are required to better understand the biochemical and molecular mechanism of Si on organogenesis and somatic embryogenesis.

\section{GROWTH AND DEVELOPMENT}

The application of Si has been reported to enhance the growth and development of various plants. Zhou (1995) observed silica bodies in leaf tissues of Phalaenopsis hybrid plantlets grown in Vacin and Went medium supplemented with $\mathrm{CaSiO}_{3}$. Addition of $\mathrm{CaSiO}_{3}$ also increased the leaf length. Soares et al. (2011) reported that the addition of $5.0 \mathrm{mg} \mathrm{L}^{-1} \mathrm{~K}_{2} \mathrm{SiO}_{3}$ and $20.0 \mathrm{mg}$ $\mathrm{L}^{-1} \mathrm{Na}_{2} \mathrm{SiO}_{3}$ to the modified Knudson $\mathrm{C}$ medium increased the number of roots and length of aerial part and root in seedlings of C. loddigesii. Subsequently the same group investigated the effect of $\mathrm{GA}_{3}$ and $\mathrm{Na}_{2} \mathrm{SiO}_{3}$ on growth and development of $C$. loddigesii (Soares et al., 2013). It was reported that the combination of $\mathrm{GA}_{3}$ and $\mathrm{Na}_{2} \mathrm{SiO}_{3}$ increased the number of leaves and roots than $\mathrm{GA}_{3}$ alone. The optimal concentration of $\mathrm{Si}$ varies within the same plant species and or genotype. The inclusion of $\mathrm{CaSiO}_{3}$ at 0.5 and $2.0 \mathrm{mg} \mathrm{L}{ }^{-1}$ to the MS medium stimulates the growth of native (Brassavolva perrinii) and hybrid (Laelia cattleya 'Culminant Tuilerie' $\times$ L. cattleya 'Sons Atout Rotunda') $\times$ Brassolaelia cattleya 'Startifire Moon Beach') orchid plants, respectively (Soares et al., 2012). Lim et al. (2012) also reported that the effect of $\mathrm{Si}\left(\mathrm{K}_{2} \mathrm{SiO}_{3}\right)$ on the growth traits of begonia 'Super Olympia Red' and 'Super Olympia Rose' and pansy 'Matrix White Blotch' and 'Matrix Yellow Blotch' are mainly dependent on the cultivars. Braga et al. (2009) investigated the effect of different Si sources such as $\mathrm{CaSiO}_{3}, \mathrm{~K}_{2} \mathrm{SiO}_{3}$, and $\mathrm{Na}_{2} \mathrm{SiO}_{3}$ on the growth and anatomical characteristics of strawberry 'Oso Grande' seedlings. The fresh and dry weight of seedlings increased in MS medium containing $1.0 \mathrm{~g} \mathrm{~L}^{-1} \mathrm{Na}_{2} \mathrm{SiO}_{3}$. Seedlings of banana 'Maca' cultured in the medium supplemented with $\mathrm{CaSiO}_{3}$ increased the chlorophyll content, whereas those cultured in the medium containing $\mathrm{Na}_{2} \mathrm{SiO}_{3}$ increased length, fresh and dry weight of shoots (Asmar et al., 2011).

The morphological and anatomical characteristics of in vitrogrown plantlets are different from the field-grown seedlings. Si inclusion to the rooting medium increased leaf tissue thickness and epicuticular wax deposition in banana (Asmar et al., 2013a) and strawberry (Braga et al., 2009) plantlets. Luz et al. (2012) reported that supplementation of $\mathrm{CaSiO}_{3}, \mathrm{~K}_{2} \mathrm{SiO}_{3}$, or $\mathrm{Na}_{2} \mathrm{SiO}_{3}$ to the rooting medium improved leaf anatomy of banana 'Maca' plantlets. The inclusion of $\mathrm{CaSiO}_{3}$ to the culture medium also increased photosynthetic rate and chlorophyll content of banana plantlets (Asmar et al., 2013b). In strawberry, light and electron microscopic analysis showed deformation in chlorenchyma and the epidermis of leaves from plantlets grown in the culture medium devoid of Si (Soares et al., 2012). Recently, He et al. (2013) confirmed the deposition of Si within the cell walls of in vitro-cultured rice cells. Si improves the structural stability of cell walls during cell elongation and division and thereby maintained cell shape, which may be important for the function and survival of cells (Table 1).

Ziv (2010) investigated the effect of silicon on hyperhydricity in Ornithogalum dubium. Addition of $\mathrm{Na}_{2} \mathrm{SiO}_{3}$ to MS liquid medium containing BA, NAA and $6 \%$ sucrose in bioreactors, significantly reduced induction of hyperhydric shoots, and increased plant firmness and mechanical strength. Si treatment significantly reduced the content of hydrogen peroxide and activity of oxidative reductive enzymes such as APX, ascorbate oxidase and GPX in leaves of the regenerated shoots of $O$. dubium when compared with the control (Table 1). Similarly, addition of $\mathrm{Si}$ as $\mathrm{K}_{2} \mathrm{SiO}_{3}$ to $\mathrm{MS}$ medium reduced the hyperhydricity in Cotoneaster wilsonii by decreasing the content of MDA in the regenerated shoots when compared with the control (Sivanesan et al., 2011). The authors observed the presence of Si in the in non-hyperhydric plants, but not in the hyperhydric leaf samples of $C$. wilsonii by energy dispersive $X$-ray analysis. Thus, the problem of hyperhydricity can be reduced by the inclusion of Si to both liquid and solid culture medium. Phenolic oxidative tissue browning is one of the bottlenecks in woody plant tissue culture. In guava, tissue browning was completely prevented by sealing the nodal explants cut ends with Si (Youssef et al., 2010) and there was no detrimental effect of Si on the subsequent steps of in vitro propagation. The authors suggested that Si could be used during explants preparation to control phenolic tissue browning in other plants. The morphological, anatomical and physiological characteristics of plantlets can improve in vitro by incorporating $\mathrm{Si}$ in the culture medium. However, further studies required to evaluate the effect of different source and concentration of silicon on the growth and development of various plants.

\section{ABIOTIC STRESS TOLERANCE}

Duan et al. (2013) reported that Si enhance cold resistance of Dendrobium moniliforme by increasing the content of free proline, soluble sugar and soluble protein and decreasing MDA content. Si treatment improved the survival rate of grape 'Kyoho' and 'koshusanjaku' calli under low temperature by preventing browning (Moriguchi et al., 1988). In vitro storage of Coleus hybridus 'Jupiter' and Solanum tuberosum var. Gersa under silicone oil significantly reduced the growth and maintained their regenerative potential (Radovet et al., 2008; Radovet-Salinschi and Cachita-Cosma, 2012). These results reveal that Si can be used as cryoprotectant and included in the cryoprotective mixture for minimizing the toxicity of cryoprotectants. The ameliorating effect of Si on 
Table 1 | Role of Si in plant tissue culture.

\begin{tabular}{|c|c|c|}
\hline Plant species & Role of Si & Reference \\
\hline \multirow[t]{2}{*}{ Ajuga multiflora } & Increased frequency of shoot regeneration & Sivanesan and Jeong (2014) \\
\hline & Increased resistance to $\mathrm{NaCl}$ & \\
\hline Begonia semperflorens & Increased growth, biomass and chlorophyll content & Lim etal. (2012) \\
\hline Brassavola perrinii Hybrid orchid & $\begin{array}{l}\text { Increased seedlings growth, favorable characteristics in the leaf } \\
\text { anatomy of the orchid seedlings }\end{array}$ & Soares et al. (2012) \\
\hline \multirow[t]{2}{*}{ Cattlleya loddigesii } & Increased the number of shoots & Soares etal. (2011) \\
\hline & Increased growth traits of seedlings & Soares et al. (2013) \\
\hline Coleus hybridus & Maintained regenerative potential of vitroplantlets & Radovet et al. (2008) \\
\hline Cotoneaster wilsonii & Reduced hyperhydricity & Sivanesan etal. (2011) \\
\hline Dendrobium moniliforme & Increased resistance to low temperature & Duan etal. (2013) \\
\hline Fragaria $\times$ ananassa & $\begin{array}{l}\text { Increased biomass, thickness of leaf tissues and epicuticular wax } \\
\text { deposition }\end{array}$ & Braga et al. (2009) \\
\hline Musa sp. 'Grande Naine' & Well-developed stomata, Increased epicuticular wax layer in leaves & Asmar et al. (2013a) \\
\hline \multirow[t]{3}{*}{ Musa sp. 'Maca' banana } & Increased chlorophyll content, biomass and seedlings growth & Asmar et al. (2011) \\
\hline & Improved leaf anatomy & Luz et al. (2012) \\
\hline & Improved morpho-physiological leaf characteristics of seedlings & Asmar et al. (2013b) \\
\hline Ornithogalum dubium & Reduced hyperhydricity and improving leaf structure and ex vitro & Ziv (2010) \\
\hline & survival during acclimatization & \\
\hline \multirow[t]{2}{*}{ Oryza sativa } & Improved callus induction, and plant regeneration & Islam etal. (2005) \\
\hline & Improved structural stability of cell walls & He et al. (2013) \\
\hline Perilla frutescens & Increased the growth rate and content of anthocyanins & Zhong et al. (1992) \\
\hline Phalaenopsis hybrid & Increased shoot growth & Zhou (1995) \\
\hline Phragmites australis & Stimulated callus growth, somatic embryogenesis and root formation & Mathe et al. (2012) \\
\hline Picea abies & Ameliorated the effect of $\mathrm{Al}$ & Prabagar etal. (2011) \\
\hline Psidium guajava & Inhibiting phenol-based browning & Youssef etal. (2010) \\
\hline Salvia splendens & Increased resistance to $\mathrm{NaCl}$ & Soundararajan et al. (2013) \\
\hline Solanum tuberosum var. Gersa & Maintained regenerative potential of vitroplantlets & Radovet-Salinschi and Cachita-Cosma (2012) \\
\hline S. tuberosum & Increased growth, biomass and tolerance to $\mathrm{NaCl}$ & Qing et al. (2005) \\
\hline Viola $\times$ wittrockiana & Increased growth, biomass and chlorophyll content & Lim etal. (2012) \\
\hline Vitis vinifera $\times$ V. labrusca & Increased the survival rate of callus under low temperature & Moriguchi etal. (1988) \\
\hline
\end{tabular}

salt stress in vitro has been reported in A. multiflora (Sivanesan and Jeong, 2014), Salvia splendens 'Hot Jazz' (Soundararajan et al., 2013) and S. tuberosum (Qing et al., 2005). Si alleviates salt stress in plants by limiting $\mathrm{NaCl}$ uptake, maintenance of ultrastructure of stomata, improving photosynthetic activity, reducing free proline content and altering the production of antioxidant enzymes (Qing et al., 2005; Soundararajan et al., 2013; Sivanesan and Jeong, 2014). Prabagar et al. (2011) investigated the effect of Si on aluminium $(\mathrm{Al})$ tolerance in Picea abies suspension cultures. $\mathrm{Al}$ toxicity was reduced when the liquid medium was supplemented with $\mathrm{Si}$ and the effect was increased at $\mathrm{pH} 5.0$ than $\mathrm{pH}$ 4.2. Si supplementation protected $P$. abies cells and against Al toxicity by reducing the concentration of free $\mathrm{Al}$ in the cell wall. $\mathrm{Si}$ is also reported to enhance drought tolerance, alleviate lead toxicity and increase resistance to radiation and temperature stresses (Balakhnina and Borkowska, 2013; Zhu and Gong, 2014). The molecular mechanisms of Si on stress tolerance are poorly understood. Thus, more studies are needed to find out the role of Si in abiotic tolerance on various plants.

\section{FUTURE PROSPECTS}

Recent studies have shown the beneficial effects of Si in plant tissue culture (Table 1). However, further studies on a wide variety of plant species are needed to confirm the role of $\mathrm{Si}$ in plant tissue culture. In vitro culture is a useful system for studying physiological and biochemical functions of Si in plants at molecular level. Further, in vitro cell suspension culture systems provide an opportunity to study roles of $\mathrm{Si}$ at the single cell level. The inclusion of silicone A to Linsmaier and Skoog liquid medium also enhances cell growth and anthocyanins content in cell suspension culture of Perilla frutescens (Zhong et al., 1992). Thus, Si can also be used for the stimulation of secondary metabolites in the plant cell, tissue 
and organ cultures. We strongly recommend the inclusion of $\mathrm{Si}$ as a beneficial nutrient in the tissue culture medium to solve various micropropagation problems, and to increase tissue culture success.

\section{ACKNOWLEDGMENT}

This article was supported by the KU Research Professor Program of Konkuk University.

\section{REFERENCES}

Asmar, S. A., Pasqual, M., de Araujo, A. G., Silva, R. A. L., Rodrigues, F. A., and Pio, L. A. S. (2013a). Morphophysiological characteristics of acclimatized "Grande Naine" banana plants in response to in vitro use of silicon. Cienc. Agrar. 34, 73-82.

Asmar, S. A., Castro, E. M., Pasqual, M., Pereira, F. J., and Soares, J. D. R. (2013b). Changes in leaf anatomy and photosynthesis of micropropagated banana plantlets under different silicon sources. Sci. Hortic. 161, 328-332. doi: 10.1016/j.scienta.2013.07.021

Asmar, S. A., Pasqual, M., Rodrigues, F. A., de Araujo, A. G., Pio, L. A. S., and e Silva, S. O. (2011). Sources of silicon in the development of micropropagated seedlings of banana "Maçã." Cienc. Rural. 41, 1127-1131. doi: 10.1590/S010384782011005000086

Balakhnina, T., and Borkowska, A. (2013). Effects of silicon on plant resistance to environmental stresses: review. Int. Agrophys. 27, 225-232. doi: 10.2478/v10247012-0089-4

Braga, F. T., Nunes, C. F., Favero, A. C., Pasqual, M., Carvalho, J. G., and Castro, E. M. (2009). Anatomical characteristics of the strawberry seedlings micropropagated using different sources of silicon. Pesqui. Agropecu. Bras. 44, 128-132. doi: 10.1590/S0100-204X2009000200003

Duan, X., Tang, M., and Wang, W. (2013). Effects of silicon on physiology and biochemistry of dendrobium moniliforme plantlets under cold stress. Agric. Biotechnol. 2, 18-21. doi: 10.1007/s13593-011-0039-8

Epstein, E. (1999). Silicon. Annu. Rev. Plant. Physiol. Plant Mol. Biol. 50, 641-664. doi: 10.1146/annurev.arplant.50.1.641

He, C., Wang, L., Liu, J., Liu, X., Li, X., Ma, J., et al. (2013). Evidence for "silicon" within the cell walls of suspension-cultured rice cells. New Phytol. 200, 700-709. doi: $10.1111 / \mathrm{nph} .12401$

Islam, M. M., Ahmed, M., and Mahaldar, D. (2005). In vitro callus induction and plant regeneration in seed explants of rice (Oryza sativa L.). Res. J. Agri. Biol. Sci. $1,72-75$.

Lim, M. Y., Lee, E. J., Jana, S., Sivanesan, I., and Jeong, B. R. (2012). Effect of potassium silicate on growth ad leaf epidermal characteristics of begonia and pansy grown in vitro. Kor. J. Hort. Sci. Technol. 30, 579-585.

Luz, J. M. Q., Asmar, S. A., Pasqual, M., de Araujo, A. G., Pio, L. A. S., and Resende, R. F. (2012). Modification in leaf anatomy of banana plants cultivar "Maca" subjected to different silicon sources in vitro. Acta Hort. 961, 239-243.

Ma, J. F. (2004). Role of silicon in enhancing the resistance of plants to biotic and abiotic stresses. Soil Sci. Plant Nutr. 50, 11-18. doi: 10.1080/00380768.2004.10408447

Mathe, C., Mosolygo, A., Suranyi, G., Beke, A., Demeter, Z., Toth, V. R., et al. (2012). Genotype and explants-type dependent morphogenesis and silicon response of common reed (Phragmites australis) tissue cultures. Aquat. Bot. 97, 57-63. doi: 10.1016/j.aquabot.2011.11.005

Moriguchi, T., Kozaki, I., Matsuta, N., and Yamaki, S. (1988). Plant regeneration from grape callus stored under a combination of low temperature and silicone treatment. Plant Cell Tissue Organ Cult. 15, 67-71. doi: 10.1007/BF000 39890

Prabagar, S., Hodson, M. J., and Evans, D. E. (2011). Silicon amelioration of aluminium toxicity and cell death in suspension cultures of Norway spruce (Picea abies L.). Environ. Exp. Bot. 70, 266-276. doi: 10.1016/j.envexpbot.2010.10.001

Qing, W., Huiying, H., and Jinwen, Z. (2005). Effect of exogenous silicon and proline on potato plantlet in vitro under salt stress. China Vegetables 9, 16-18.

Radovet, D., Cachita-Cosma, D., and Petrus, A. (2008). The micropropagation of Coleus hybridus Jupiter vitrocultures under different paraffin or silicon oil stratums. Studia Universitatis "Vasile Goldiş", Seria Ştiinte Vieţii (Life Sciences Series)18, 61-70

Radovet-Salinschi, D., and Cachita-Cosma, D. (2012). Testing the regenerative capacity of Solanum tuberosum var. Gersa explants after 24 weeks storage in living collection. Analele Universităţii din Oradea, Fascicula: Ecotoxicologie, Zootehnie şi Tehnologii de Industrie Alimentară? 11, 423-430.

Reed, B. M., Wada, S., DeNoma, J., and Niedz, R. P. (2013). Mineral nutrition influences physiological responses of pear in vitro. In Vitro Cell. Dev. Biol. Plant 49, 699-709. doi: 10.1007/s11627-013-9556-2

Sivanesan, I., and Jeong, B. R. (2014). Silicon promotes adventitious shoot regeneration and enhances salinity tolerance of Ajuga multiflora Bunge by altering activity of antioxidant enzyme. Sci. World J. 2014, 10 doi: 10.1155/2014/521703

Sivanesan, I., Song, J. Y., Hwang, S. J., and Jeong, B. R. (2011). Micropropagation of Cotoneaster wilsonii Nakai-a rare endemic ornamental plant. Plant Cell Tissue Organ Cult. 105, 55-63. doi: 10.1007/s11240-010-9841-2

Soares, J. D. R., Pasqual, M., de Araujo, A. G., De Castro, E. M., Pereira, F. J., and Braga, F. T. (2012). Leaf anatomy of orchids micropropagated with different silicon concentrations. Acta Sci. Agron. 34, 413-421. doi: 10.4025/actasciagron.v34i4.15062

Soares, J. D. R., Pasqual, M., Rodrigues, F. A., Villa, F., and de Araujo, A. G. (2011). Silicon sources in the micropropagation of the Cattleya group orchid. Acta Sci. Agron. 33, 503-507.

Soares, J. D. R., Villa, F., Rodrigues, F. A., and Pasqual, M. (2013). Concentrations of silicon and GA3 in in vitro propagation of orchids under natural light. Sci. Agrar. Parana. 12, 286-292.

Soundararajan, P., Sivanesan, I., Jo, E. H., and Jeong, B. R. (2013). Silicon promotes shoot proliferation and shoot growth of Salvia splendens under salt stress in vitro. Hort. Environ. Biotechnol. 54, 311-318. doi: 10.1007/s13580-013-0118-7

Van Bockhaven, J., De Vleesschauwer, D., and Höfte, M. (2013). Towards establishing broad-spectrum disease resistance in plants: silicon leads the way. J. Exp. Bot. 64, 1281-1293. doi: 10.1093/jxb/ers329

Voogt, W., and Sonneveld, C. (2001). "Silicon in horticultural crops grown in soilless culture," in Silicon in Agriculture, eds L. E. Datnoff, G. H. Snyder, and G. H. Korndorfer (Amsterdam: Elsevier Science), 115-131.

Youssef, M. A., El-Helw, M. R., Taghian, A. S., and El-Aref, H. M. (2010). Improvement of Psidium guajava L. using micropropagation. Acta Hort. 849, 223-230.

Zhong, J. J., Seki, T., Kinoshita, S. I., and Yoshida, T. (1992). Effects of surfactants on cell growth and pigment production in suspension cultures of Perilla frutescens. World J. Microbiol. Biotechnol. 8, 106-108. doi: 10.1007/BF01195826

Zhou, T. S. (1995). The detection of the accumulation of silicon in Phalaenopsis (Orchidaceae). Ann. Bot. 75, 605-607. doi: 10.1006/anbo.1995.1065

Zhu, Y., and Gong, H. (2014). Beneficial effects of silicon on salt and drought tolerance in plants. Agron. Sustain. Dev. 34, 455-472. doi: 10.1007/s13593-0130194-1

Ziv, M. (2010). Silicon effects on growth acclimatization and stress tolerance of bioreactor cultured Ornithogalum dubium plants. Acta Hort. 865, 29-36.

Conflict of Interest Statement: The authors declare that the research was conducted in the absence of any commercial or financial relationships that could be construed as a potential conflict of interest.

Received: 01 August 2014; accepted: 04 October 2014; published online: 21 October 2014.

Citation: Sivanesan I and Park SW (2014) The role of silicon in plant tissue culture. Front. Plant Sci. 5:571. doi: 10.3389/fpls.2014.00571

This article was submitted to Plant Nutrition, a section of the journal of Frontiers in Plant Science.

Copyright (C) 2014 Sivanesan and Park. This is an open-access article distributed under the terms of the Creative Commons Attribution License (CC BY). The use, distribution or reproduction in other forums is permitted, provided the original author(s) or licensor are credited and that the original publication in this journal is cited, in accordance with accepted academic practice. No use, distribution or reproduction is permitted which does not comply with these terms. 